\title{
Mechanisms of aural encoding: IV. Hear-see, say-write interactions for vowels
}

\author{
BRUCE DENNIS SALES AND RALPH NORMAN HABER, ${ }^{2}$ UNIVERSITY OF ROCHESTER \\ RONALD A. COLE, UNIVERSITY OF CALIFORNIA AT RIVERSIDE
}

\begin{abstract}
Six vowel sounds were presented in random orders for recall from short-term memory. Four groups of $25 \mathrm{Ss}$ each in a 2 by 2 design either heard or saw the words, and either had to say them or write them. In general, accuracy was greater when the sounds were seen rather than heard, especially when they were verbally reported. The major concern was the degree to which the major distinctive feature systems could predict the intrusion errors in each of the four conditions. The best prediction occurred in the auditory-input/verbal-output condition, as would be expected from the models on which distinctive feature specifications are based. However, as in a previous study by these authors, the most accurate predictions were not always made by the same combination of distinctive features. It is concluded that distinctive features are identified in the initial encoding before any retrieval processes are activated and that further errors made at the time of retrieval are also related to distinctive features. Most importantly, however, both at initial registration and at retrieval, different features are implicated, depending upon the sound presented for recall and the input-output modalities involved.
\end{abstract}

In a previous study using a short-term serial recall task, Sales, Haber, and Cole (1968) found that intrusion errors in the encoding of vowels could not be predicted perfectly by any of several distinctive feature systems tested. These results are consistent with a coding model presented by Liberman, Cooper, Shankweiler, and Studdert-Kennedy (1967), who contended that vowels are encoded not like consonants but in a manner similar to complex nonspeech sounds. However, Wickelgren (1965) found that vowel intrusions could be predicted with $100 \%$ accuracy using a distinctive feature system with two dimensions: place of articulation (front, back) or openness of the vocal tract (narrow, medium, and wide).

An examination of the methodology of the two empirical experiments showed important differences in both the stimuli and procedures. Wickelgren used the vowels $/ I, \epsilon$, ae, $U, \Lambda$, and $a /$, all six of which were presented for recall on each trial. These sounds had no open-close or tense-lax variants. Sales, Haber, and Cole used sequences of six or seven sounds, drawn from a set of nine vowels $/ i, I, e$, ae, $a, u_{2} U, o, \supset /$. Three of these pairs (i I, $u U, \supset$ a) were distinguished by the open-close feature

The failure of any of the distinctive feature models to predict the data perfectly in the Sales, Haber, and Cole study may have been due to the presence of the open-close variants in that study. Their finding that different dimensions predict different sounds accurately suggests that for some sounds different dimensions are differentially important. Thus, when open-close variants are presented in the same sequence for recall; this feature may become critical in the encoding task. Sounds that differ only by a tense-lax distinction force a perceptually difficult discrimination. Therefore, if this distinction is eliminated in the stimuli, a distinctive feature model should predict the pattern of errors with $100 \%$ accuracy.

The second major difference between the two experiments concerned the input modality of the stimuli and the response mode required of Ss. Wickelgren's Ss copied the sounds as they were heard and then wrote their responses immediately after copying the last sound. The Ss in the Sales, Haber, and Cole study heard the sounds and then vocalized their responses $3 \mathrm{sec}$ after hearing the last sound.

It seems likely that differences in the encoding process will occur between visually and auditorily presented vowels. For example, it is possible with visual input that the stimulus must be first identified and then recoded into the auditory trace. No such recoding may be necessary when the input is auditory. To the extent that this is true, the auditory input procedures requires less encoding. Further, the visual input probably has some extra visual encoding stages in which, if errors do occur, they are not likely to be related to auditory-based confusions, such as would be predicted by a distinctive feature model.

In order to clarify the role of distinctive features in the encoding of vowel sounds, the present experiment was undertaken. Sequences of $\operatorname{six} \operatorname{stimuli}(I, \epsilon$, ae, $\supset, o, U)$ were constructed so that all six sounds were presented for recall on each trial and no open-close variants existed between any of the vowels. Further, the effect of input and output modality was examined by varying both input (hear or see) and output (say or write) in a 2 by 2 design.

\section{Subjects}

One hundred psychology students at the University of Rochester served as Ss. Their participation fulfilled $1 \mathrm{~h}$ of course requirements. They were divided into four groups of $25 \mathrm{Ss}$ each on a random basis. Each $\mathrm{S}$ was tested separately, in a session lasting about $30 \mathrm{~min}$.

\section{Stimuli}

The following words were used as stimuli: hick, heck, hack, hook, hoak, hawk. These words are composed of the vowel sounds $/ \mathrm{I} / / \epsilon / / \mathrm{ae} / / \mathrm{U} / / \mathrm{o} / \mathrm{J} / \mathrm{in}$ the environment $/ \mathrm{h}-\mathrm{k} /$. The six words were presented once each in each of 48 sequences. The 48 serial orders were randomly determined from the 720 possible orders, with the restriction that each word appear eight times in each position. When the stimuli were presented visually, they were drawn on paper tapes so that each word appeared for $1 \mathrm{sec}$ in the viewing window of an MTA 100 stimulus programmer and was then replaced (in $50 \mathrm{msec}$ ) by the next word. When they were presented auditorily, Ss heard them from a tape recording made at a rate of one sound per second.

\section{Procedure}

Two input modalities (hear and see) and two response modes (say and write) were used to form four conditions: hear-say, hear-write, see-say, and see-write. Each $S$ served in only one of the four conditions.

Hear-Say Condition

All instructions and stimuli were presented on a tape recorder. As a warm-up, $\mathrm{S}$ heard each of the six words individually. After each word, $\mathbf{S}$ spoke it out loud. If he mispronounced it, then $S$ was required to mimic E. Each word was then presented again for $S$ to repeat. 


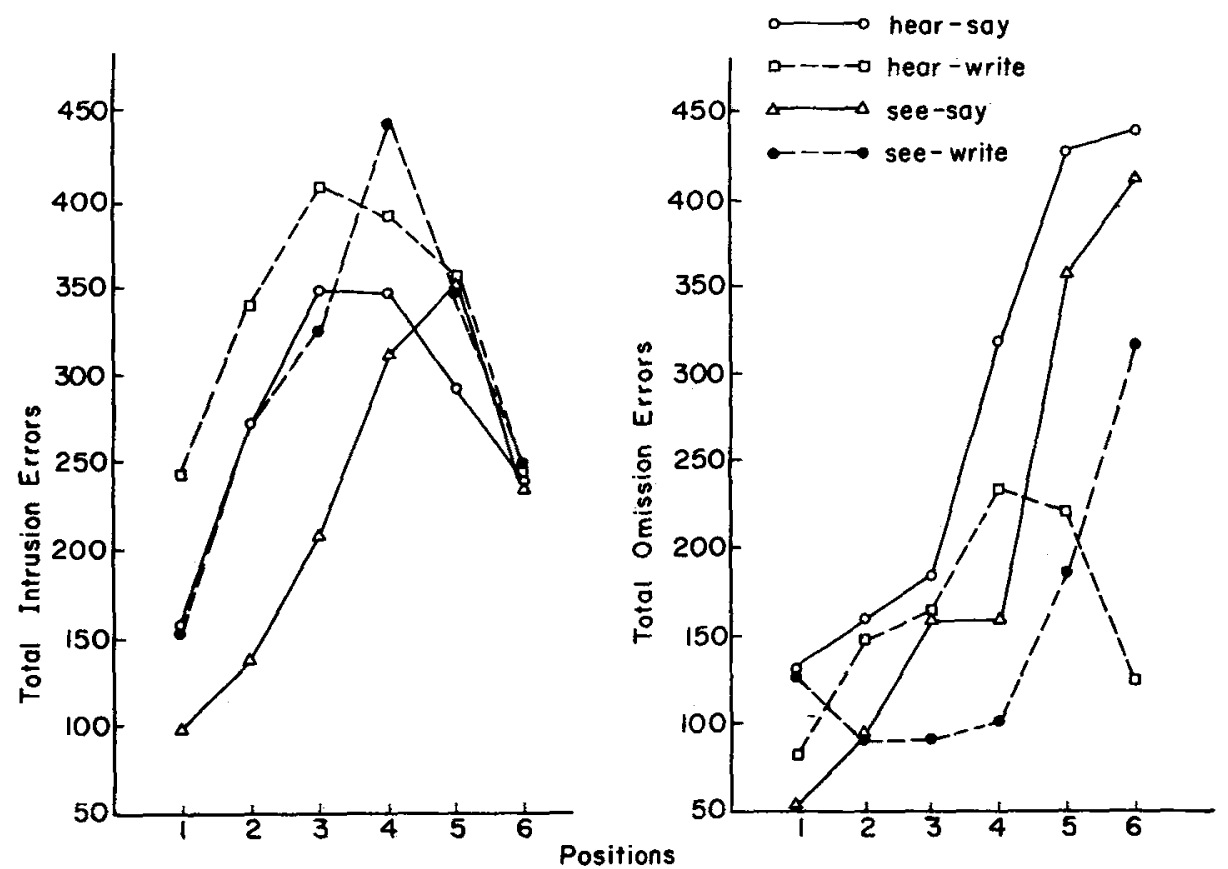

Fig. 1. Total number of intrusion and omission errors as a function of position of sound in the sequences, for each of the four conditions.
The following instructions were then heard by S: "In this experiment you will hear sequences of the six words you have just heard. All of the words will appear in each sequence although in different orders. After the last word is presented there will be a pause of $3 \mathrm{sec}$, after which you are to report back the words in the order you heard them. If you do not remember any of the words, you may say, 'Blank,' for that position. You will have as much time as you need for your report."

The $S$ then heard the sequences of words. After the signal to report was given, $\mathrm{E}$ stopped the tape recorder and wrote down on a data sheet every response and the order in which it was said.

\section{Hear-Write Condition}

All instructions and stimuli were presented on a tape recorder. The $S$ heard each of the six words separately, writing each down as he heard it. After all six words had been written, the E viewed what $S$ wrote. If the written version of the word seemed unrelated to the word as presented auditorily, the $S$ was asked to pronounce the word. If the word was pronounced correctly, the $S$ was permitted to use that spelling. Each word was heard once again, while $S$ wrote the word he had heard. The $E$ checked for any changes from the first spelling.

The $S$ then heard the following instructions: "In this experiment you will hear sequences of the six words. All of the words will occur in each sequence, although in a different order each time. Following the end of each sequence by $3 \mathrm{sec}$, write the words in the order in which they were presented in the spaces provided on the answer sheet. If you do not remember any of the words, you may leave that space blank. When you have finished writing the words, turn your answer sheet to the next page."

The $S$ then heard the sequences of words. When the signal to report was given, $E$ stopped the tape recorder, and $S$ had as much time as he needed to write his answers.

\section{See-Say Condition}

All instructions were read by $E$ from a typed sheet of paper. Each word was presented separately on the MTA, and S was told to pronounce the word. If the word was pronounced incorrectly, $E$ then said the word, and $S$ mimicked him. After all six words were presented, $S$ saw each word again for 1 sec, and was told to repeat it.

The $S$ was then given the following instrutions: "In this experiment you will see the six words in a different order each time. After the six words are presented, and following a pause of 3 sec, the word 'report' will appear on the screen, and then you should repeat the words back in the order in which you saw them. If you do not remember a word, you may say, 'Blank,' for that position."

The $S$ then saw the sequences of words. When the signal to report was given, E stopped the MTA, and $S$ had as much time as needed to report. The $\mathrm{E}$ wrote down every response made, in the order in which it was given.

\section{See-Write Condition}

All instructions were read by $E$ from a typed sheet of paper. Each word was presented separately on the MTA. While the word was present, $S$ copied it on a sheet of plain white paper. After all six words had been copied, the words were presented again in a different order for $1 \mathrm{sec}$ each, and $S$ wrote them down a second time.

Each $S$ then heard the following instructions: "In this experiment you will be presented with sequences of these six words, in a different order each time. After the six words are presented, there will be a pause of $3 \mathrm{sec}$, and then the word 'report' will appear on the screen. When you see this word, write the words in the order in which they were presented in the proper places on the answer sheet. If you do not remember any of the words, you may leave that space blank. When you have finished writing the words, turn your answer sheet to the next page."

The $S$ then saw the sequences of words. When the signal to report was given, $E$ stopped the $M T A$, and $S$ had as much time as needed to report.

\section{Scoring}

The Ss' recall was scored for two types of errors. For an intrusion error, the word was reported in the wrong serial position. For an omission, the $S$ either responded verbally with the word "blank" or left the space unfilled on the answer sheet. 
Table 1

Percent Errors, Summed Over the 6 Sounds for the Omissions and Intrusions for Each of the Four Experimental Conditions

\begin{tabular}{|c|c|c|c|c|c|c|c|}
\hline \multicolumn{4}{|c|}{ Omission Errors } & \multicolumn{4}{|c|}{ Intrusion Errors } \\
\hline \multicolumn{4}{|c|}{ Input } & & & \multicolumn{2}{|c|}{ Input } \\
\hline & & Hear & See & & & Hear & See \\
\hline Output & $\begin{array}{l}\text { Say } \\
\text { Write }\end{array}$ & $\begin{array}{l}23.6 \\
13.8\end{array}$ & $\begin{array}{l}18.6 \\
13.4\end{array}$ & Output & $\begin{array}{l}\text { Say } \\
\text { Write }\end{array}$ & $\begin{array}{l}23.0 \\
28.5\end{array}$ & $\begin{array}{l}18.4 \\
27.0\end{array}$ \\
\hline
\end{tabular}

\section{RESULTS}

Two questions are posed: What are the effects of the input-output modes on the number and type of errors made; and, if an error is made, can we predict what sound will intrude in place of the correct sound?

Table 1 presents the results regarding ie effects of input-output modalities for omission and intrusion errors. Analyses of variance showed that more omissions were made in the two Say conditions $(p<.05)$ as compared to the two Write conditions. Within the Say report mode, more omissions occurred when $S$ heard, rather than saw, the words $(p<.05)$. The pattern was somewhat reversed for the intrusion errors, with more occurring in the two Write conditions $(\mathrm{p}<.05)$ than in the two Say conditions. Within the latter, hearing the words again produced more intrusion errors than seeing them $(\mathrm{p}<.05)$.

The lower error rate with written report seems quite likely to be due to $S$ having a space for each response on his answer sheet. Thus, he knew when he omitted an item, probably guessing as a result. That would account for the higher intrusion error score under written reports. The finding that, with verbal response, fewer errors of either type are made with seeing as compared to hearing may merely reflect some differences between the discriminability of the stimuli in the two input channels.

Figure 1 presents the effects of the position of the sounds in the sequence. Omission errors show no recency effect, except for a slight improvement for the last sound in the Hear-Write condition. Intrusion errors, on the other hand, show a recency effect for all four conditions, though the primacy effect is greatest for the See-Say condition. These interactions between condition and position are significant $(p<.01)$ for both error types. Conrad and Hull (1968) found little recency for intrusion errors for their See-Write condition (the only one corresponding to any in this experiment). This discrepancy would appear to leave unresolved the effect of input modality on serial position effects.

The per cent error measures, as reported above, do not provide answers to the more interesting questions raised-if $S$ makes an error, can the particular erroneous substitute he makes be predicted? Since there is no way to know what $S$ might have reported when he omitted an answer, only the intrusion errors can be analyzed further. These analyses parallel those presented by Wickelgren (1965) and Sales, Haber, and Cole (1968).

Tables 2, 3, 4, and 5 (one for each of the four experimental conditions) contain the rank order of presented sounds for each intruded sound, based on their conditional probabilities of occurrence. For example, in Table 2; when /I/ was the intruded sound, it was reported most often when / $/$ was the presented sound and least often when $/ \supset /$ was the presented sound. Briefly, these tables were derived in the following manner: (1) For each presented sound, the number of intrusion errors and the type of error an $\mathbf{S}$ made was recorded. Results were then summed across all Ss within each condition. (2) In each condition for each presented sound, the rank order of intruded sounds was tabulated, based on the total number of times that intruded sound occurred in the place of the presented sound. (3) Then for each presented sound, the number of errors of each intruded
Table 2

Results of Hear-Say Condition, Presenting the Rank Order of Presented Sounds by the Conditional Probability that the Intruded Sound Would Occur in Its Place

\begin{tabular}{|c|c|c|c|c|c|}
\hline I & $\epsilon$ & $\begin{array}{l}\text { Intruded } \\
\text { ae }\end{array}$ & Sound & o & $\mathbf{U}$ \\
\hline $\begin{array}{c}\mathrm{U} \\
.3137\end{array}$ & $\begin{array}{c}a \mathrm{e} \\
.3916\end{array}$ & $\underset{.4322}{\in}$ & $\begin{array}{c}o \\
.3094\end{array}$ & $\stackrel{\supset}{.3279}$ & $\begin{array}{c}0 \\
.2410\end{array}$ \\
\hline$\underset{.2303}{\epsilon}$ & $\begin{array}{c}I \\
.3348\end{array}$ & 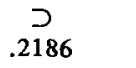 & $\begin{array}{c}\mathrm{ae} \\
.2053\end{array}$ & $\begin{array}{c}\mathbf{U} \\
.2795\end{array}$ & $\stackrel{\supset}{.2186}$ \\
\hline $\begin{array}{c}\text { ae } \\
.1597\end{array}$ & $\begin{array}{c}o \\
.1403\end{array}$ & $\begin{array}{c}I \\
.1652\end{array}$ & $\begin{array}{c}\mathrm{U} \\
.1988\end{array}$ & $\stackrel{\text { I }}{.1739}$ & $\frac{1}{.2000}$ \\
\hline $\begin{array}{c}0 \\
.1475\end{array}$ & $\begin{array}{c}\supset \\
.0972\end{array}$ & $\begin{array}{c}0 \\
.1619\end{array}$ & $\begin{array}{c}I \\
.1261\end{array}$ & $\begin{array}{c}\text { ae } \\
.1635\end{array}$ & $\begin{array}{c}\text { ae } \\
.0798\end{array}$ \\
\hline $\begin{array}{c}\supset \\
.1377 \\
\end{array}$ & $\begin{array}{c}\mathrm{U} \\
.0901 \\
\end{array}$ & $\begin{array}{c}\mathrm{U} \\
.1180\end{array}$ & $\begin{array}{c}\epsilon \\
.1167\end{array}$ & $\underset{.1451}{E}$ & $\underset{.0757}{E}$ \\
\hline
\end{tabular}

Table 3

Results of Hear-Write Condition, Presenting the Rank Order of Presented Sounds by the Conditional Probability that the Intruded Sound Would Occur in Its Place

\begin{tabular}{|c|c|c|c|c|c|}
\hline I & $\in$ & $\begin{array}{l}\text { Intruded } \\
\text { ae }\end{array}$ & Sound & $\mathbf{o}$ & $\mathbf{U}$ \\
\hline$\underset{.2381}{\epsilon}$ & $\underset{.3136}{I}$ & $\underset{.3894}{\epsilon}$ & $\begin{array}{c}\mathrm{ae} \\
.2529\end{array}$ & $\begin{array}{c}\mathbf{U} \\
.3109\end{array}$ & $\begin{array}{c}0 \\
.3256\end{array}$ \\
\hline $\begin{array}{c}\mathrm{U} \\
.2185\end{array}$ & $\begin{array}{c}\text { ae } \\
.2882\end{array}$ & $\begin{array}{c}\supset \\
.2746\end{array}$ & $\begin{array}{c}0 \\
.1816\end{array}$ & $\stackrel{\supset}{.2644}$ & $\begin{array}{c}I \\
.2160\end{array}$ \\
\hline $\begin{array}{c}0 \\
.1614\end{array}$ & $\begin{array}{c}0 \\
.1816\end{array}$ & $\begin{array}{c}I \\
.1707\end{array}$ & $\begin{array}{c}\mathrm{U} \\
.1793\end{array}$ & $\begin{array}{c}I \\
.1847\end{array}$ & $\stackrel{\supset}{.2068}$ \\
\hline $\begin{array}{c}\text { ae } \\
.1529\end{array}$ & $\begin{array}{c}\mathrm{U} \\
.1765\end{array}$ & $\begin{array}{c}0 \\
.1499\end{array}$ & $\begin{array}{c}1 \\
.1150\end{array}$ & $\underset{.1597}{\in}$ & $\begin{array}{c}\text { ae } \\
.1500\end{array}$ \\
\hline $\begin{array}{c}\supset \\
.1017 \\
\end{array}$ & $\begin{array}{c}\supset \\
.1525 \\
\end{array}$ & $\begin{array}{c}\mathrm{U} \\
.1148 \\
\end{array}$ & $\begin{array}{c}\epsilon \\
.1120\end{array}$ & $\begin{array}{c}\text { ae } \\
.1559\end{array}$ & $\underset{.1008}{E}$ \\
\hline
\end{tabular}

Table 4

Results of See-Say Condition, Presenting the Rank Order of Presented Sound by the Conditional Probability that the Intruded Sound Would Occur in Its Place

\begin{tabular}{|c|c|c|c|c|c|}
\hline I & $\in$ & $\begin{array}{l}\text { Intruded } \\
\text { ae }\end{array}$ & Sound & 0 & $\mathbf{U}$ \\
\hline $\begin{array}{c}U \\
.4074\end{array}$ & $\begin{array}{c}\text { ae } \\
.6183\end{array}$ & $\underset{.5985}{\in}$ & $\begin{array}{c}\circ \\
.3473\end{array}$ & $\stackrel{\supset}{.4061}$ & $\begin{array}{c}I \\
.4803\end{array}$ \\
\hline $\begin{array}{c}0 \\
.1916\end{array}$ & $\underset{.1790}{I}$ & $\begin{array}{c}\supset \\
.1576\end{array}$ & $\begin{array}{c}\mathrm{U} \\
.1276\end{array}$ & $\begin{array}{c}\mathrm{U} \\
.2305\end{array}$ & $\begin{array}{c}0 \\
.2395\end{array}$ \\
\hline$\underset{.1776}{E}$ & $\begin{array}{c}\mathrm{U} \\
.1399\end{array}$ & $\begin{array}{c}\circ \\
.1138\end{array}$ & $\begin{array}{c}\mathrm{ae} \\
.1031\end{array}$ & $\begin{array}{c}I \\
.1747\end{array}$ & .2121 \\
\hline .2 & $\begin{array}{c}0 \\
.1079\end{array}$ & $\begin{array}{c}\mathrm{U} \\
.0947\end{array}$ & $\begin{array}{c}I \\
.0742\end{array}$ & $\begin{array}{c}\text { ae } \\
.0992\end{array}$ & $\underset{.0772}{\epsilon}$ \\
\hline $\begin{array}{c}\text { ae } \\
.1069 \\
\end{array}$ & $\begin{array}{c}\supset \\
.0606\end{array}$ & $\begin{array}{c}\text { I } \\
.0917 \\
\end{array}$ & $\underset{.0502}{\in}$ & $\underset{.0965}{\in}$ & $\begin{array}{c}\mathrm{ae} \\
.0725\end{array}$ \\
\hline
\end{tabular}

Table 5

Results of See-Write Condition, Presenting the Rank Order of Presented Sounds by the Conditional Probability that the Intruded Sound Would Occur in Its Place

\begin{tabular}{|c|c|c|c|c|c|}
\hline I & $\epsilon$ & $\begin{array}{c}\text { Intru } \\
\text { ae }\end{array}$ & Sound & o & $\mathbf{U}$ \\
\hline$\underset{.3287}{E}$ & $\begin{array}{c}\text { I } \\
.3039\end{array}$ & $\stackrel{2}{2693}$ & $\begin{array}{c}\text { ae } \\
.3147\end{array}$ & $\stackrel{\supset}{.2407}$ & $\begin{array}{c}I \\
.3301\end{array}$ \\
\hline $\begin{array}{c}\mathbf{U} \\
.2730\end{array}$ & $\begin{array}{c}U \\
.1946\end{array}$ & $\begin{array}{c}0 \\
.2074\end{array}$ & $\begin{array}{c}0 \\
.2260\end{array}$ & $\underset{.2098}{\epsilon}$ & $\begin{array}{c}0 \\
.2539\end{array}$ \\
\hline $\begin{array}{c}\mathrm{ae} \\
.1503\end{array}$ & $\begin{array}{c}0 \\
.1920\end{array}$ & $\begin{array}{c}\mathrm{U} \\
.1811\end{array}$ & $\begin{array}{c}\mathrm{U} \\
.1541\end{array}$ & $\begin{array}{c}\text { ae } \\
.1993\end{array}$ & $\begin{array}{c}\supset \\
.2378\end{array}$ \\
\hline$\stackrel{2}{.1404}$ & $\begin{array}{c}\mathrm{ae} \\
.1853\end{array}$ & $\underset{.1329}{\epsilon}$ & $\begin{array}{c}I \\
.1209\end{array}$ & $\begin{array}{c}U \\
.1973\end{array}$ & $\underset{.2203}{\in}$ \\
\hline $\begin{array}{c}0 \\
.1207 \\
\end{array}$ &.$\stackrel{\supset}{1117}$ & $\begin{array}{c}1 \\
.1242 \\
\end{array}$ & $\begin{array}{c}E \\
.1084 \\
\end{array}$ & $\begin{array}{c}1 \\
.1209 \\
\end{array}$ & $\begin{array}{r}\text { ae } \\
.1503 \\
\end{array}$ \\
\hline
\end{tabular}


Table 6

The Articulatory Placement of Vowels Used in This Experiment, According to a Traditional Articulatory Analysis (TAA, from Pike, 1947), or the Conventional Phonetic Alphabet (CPA)

\begin{tabular}{llcr}
\hline High & & Front & Back \\
\hline \multirow{2}{*}{ Mid } & Close & & \\
& Open & I & U \\
Low & Close & $\in$ & 0 \\
& Open & ae & \\
\hline
\end{tabular}

Table 7

The Distinctive Feature Composition of the Vowels in Oux Experiment as Suggested by Halle (1962). Only Those Distinctive Features are Presented Which Differentiate the Vowels

\begin{tabular}{llllllll}
\hline & Sound & i & e & ae & J & o & u \\
\hline E & Flat & - & - & - & + & + & + \\
总 & Compact & - & - & + & + & - & - \\
Diffuse & + & - & - & - & - & + \\
Grave & - & - & - & + & + & + \\
\hline
\end{tabular}

Note: Halle's $/ i /, / e /$, and $/ u /$ are equivalent, respectively, to our $/ I /, \mid \in /$, and $/ U /$.

Table 8

Percentage of Correct Binary Predictions for Three Feature Systems, Using a Shared Feature Hypothesis. Scores are presented for all four experimental conditions.

Percentage of Correct Binary Predictions

\begin{tabular}{|c|c|c|c|c|c|}
\hline System & Dimension $\mathbf{H}$ & Hear-Say & Hear-Write & See-Say & See-Write \\
\hline $\begin{array}{l}\text { CPA } \\
\text { or } \\
\text { TAA }\end{array}$ & $\begin{array}{l}\text { (1) height of tongue } \\
\text { (2) front-backness } \\
\text { (3) both (1) \& (2) }\end{array}$ & $\begin{array}{r}89 \\
58 \\
100\end{array}$ & $\begin{array}{l}83 \\
67 \\
94\end{array}$ & $\begin{array}{l}72 \\
58 \\
78\end{array}$ & $\begin{array}{l}58 \\
83 \\
81\end{array}$ \\
\hline Halle & $\begin{array}{l}\text { (1) flat } \\
\text { (2) compact } \\
\text { (3) diffuse } \\
\text { (4) grave } \\
\text { (5) (1) \& (2) \& } \\
\text { (3) \& (4) }\end{array}$ & $\begin{array}{l}88 \\
56 \\
66 \\
88 \\
\\
91\end{array}$ & $\begin{array}{l}83 \\
78 \\
56 \\
83 \\
\\
88\end{array}$ & $\begin{array}{l}72 \\
66 \\
66 \\
72 \\
72\end{array}$ & $\begin{array}{l}58 \\
75 \\
75 \\
58 \\
\\
59\end{array}$ \\
\hline
\end{tabular}

sound was divided by the total number of intrusion errors for that presented sound. Rank orderings of intrusion errors for each presented sound are then based upon the conditional probabilities. (4) Tables 2, 3, 4, and 5, which are free from response bias, are then derived by reordering the rankings so that for each intruded sound, the presented sounds are rank ordered, based upon the conditional probabilities that the intruded sound would occur given the presented sound.

These results may be compared to predictions generated from presently known distinctive feature systems. Table 6 presents a chart of the articulatory placement of the vowels, according to the Conventional Phonetic Alphabet (CPA) or a Traditional Articulatory Analysis (TAA) (Pike, 1947). Both systems yield the same predictions for the sounds used in this experiment. Table 7 presents the distinctive feature composition of the vowels, according to Halle's (1962) system. Only those features are included which differentiate the vowels. For example, Halle has a vocalic feature that need not be included here because all the sounds in this experiment would be $(+)$ on this dimension.

Using these three distinctive feature systems, binary predictions were generated concerning the ordering of the intrusion errors. These predictions were all of a shared feature nature, and were generated for each dimension, and for all the dimensions combined within a system.

Table 8 presents the per cent of correct predictions for our data for the three feature systems using a shared feature hypothesis. Inspection of this table shows that for the Hear-Say condition the intrusion data was predicted $100 \%$ when both dimensions of either the CPA or TAA were used. Using these dimensions as our baseline, it is noted that while the two Hear conditions were predicted $100 \%$ and $94 \%$ of the time, the intrusion data for the two See conditions were predicted only $78 \%$ and $81 \%$. This pattern of results, namely that intrusion errors are better predicted by distinctive feature systems for auditorily presented sounds, is also supported within Halle's system. Once again, when all dimensions are considered together, Hear conditions matched predictions $91 \%$ and $88 \%$ of the time, while See conditions matched predictions only $72 \%$ and $59 \%$.

A post hoc analysis by Sales, Haber, and Cole (1968) of their data suggested that there was no reason why one dimension (or one combination of dimensions, for that matter) should predict all sounds equally well. For example, they showed that different dimensions could be combined to predict intrusion errors $100 \%$ of the time. They also found that negative predictions (a sound which is $(+)$ on one dimension will most often be intruded by another sound which is $(-)$ on that dimension) worked almost as well as positive predictions for some of the sounds.

Tables 9 and 10 were constructed to test these two post hoc hypotheses. Table 9 lists those dimensions or their combination, using the Halle system, that best predicted the intrusion errors. Table 10 presents a similar analysis, using the CPA and TAA. Inspection of these tables shows that different dimensions predict the intrusion data almost perfectly for all dimensions. In addition, in only a few cases were negative predictions accurate.

Table 11 presents a list of those combinations of dimensions, based on Halle's system (excluding all dimensions combined), that best predict the intrusion data for each condition. It will be noted that: (1) for both Hear conditions, two combinations of dimensions predicted the data $100 \%$, while for both See conditions, no combination of dimensions could accurately predict all the sounds; and (2) the two combinations of dimensions that best predicted intrusions for the Hear-Say condition were not the same two that best predicted the intrusions for the Hear-Write condition.

\section{DISCUSSION}

The pattern of results found in this study consistently indicated that both the input and the output modality affected the processing of vowels. Auditory input yielded intrusions in short-term memory that were predicted more accurately by distinctive feature systems than the corresponding results of visually input stimuli. Thus, it was found that: (a) when all dimensions are considered together, the CPA, TAA, and Halle's system predicted the Hear conditions with great accuracy; and (b) by combining dimensions in Halle's system it is seen that two different combinations of feature dimensions were able to predict intrusion data $100 \%$ of the time for both Hear conditions, but that no combination of dimensions could yield perfect predictions for either of the See conditions.

The output modality affected the encoding process too, as shown by: (a) Although the feature systems yielded better predictions for the Hear conditions, there were always differences in accuracy of prediction between the Say and the Write output groups favoring the Say condition; and (b) different combinations of dimensions best predicted the Say and Write conditions. These results are especially evident in Table 11 . The two dimensions that predicted the Hear-Say group perfectly were not the same two dimensions that yielded $100 \%$ predictions with the Hear-Write group. ${ }^{3}$

From a linguistic point of view, distinctive feature systems are based on either articulatory movements while producing a given 
Table 9

Those dimensions, or their combination, which best predict the intrusions in all four conditions. These dimensions all taken from Halle's (1962) distinctive feature system. All refers to all dimensions combined.

\begin{tabular}{|c|c|c|c|c|c|c|c|c|c|c|c|c|c|c|}
\hline Condition & 1 & & $\epsilon$ & & ae & & $\supset$ & & 0 & & $\mathrm{U}$ & & $\begin{array}{c}\text { Total } \\
\text { Binary }\end{array}$ & $\begin{array}{c}\% \text { Correct } \\
\text { Predictions }\end{array}$ \\
\hline Hear-Say & Diffuse & $4 / 4$ & $\begin{array}{l}\text { Flat } \\
\text { All }\end{array}$ & $\begin{array}{l}6 / 6 \\
6 / 6\end{array}$ & $\begin{array}{l}\text { Flat } \\
\text { Diffuse } \\
\text { Compact } \\
\text { All }\end{array}$ & $\begin{array}{l}5 / 6 \\
5 / 6 \\
3 / 4 \\
5 / 6\end{array}$ & All & $4 / 4$ & $\begin{array}{l}\text { Flat } \\
\text { All }\end{array}$ & $\begin{array}{l}6 / 6 \\
6 / 6\end{array}$ & $\begin{array}{l}\text { Flat } \\
\text { All }\end{array}$ & $\begin{array}{l}6 / 6 \\
4 / 4\end{array}$ & & $97 \%$ \\
\hline $\begin{array}{l}\text { Hear- } \\
\text { Write }\end{array}$ & Compact & $6 / 6$ & $\begin{array}{l}\text { Flat } \\
\text { All }\end{array}$ & $\begin{array}{l}6 / 6 \\
6 / 6\end{array}$ & $\begin{array}{l}\text { Flat } \\
\text { Diffuse } \\
\text { Compact } \\
\text { All }\end{array}$ & $\begin{array}{l}5 / 6 \\
5 / 6 \\
3 / 4 \\
5 / 6\end{array}$ & Compact & $4 / 4$ & $\begin{array}{l}\text { Flat } \\
\text { All }\end{array}$ & $\begin{array}{l}6 / 6 \\
6 / 6\end{array}$ & All & $4 / 4$ & $31 / 32$ & $97 \%$ \\
\hline See-Say & $\begin{array}{l}\text { Compact } \\
\text { Diffuse }\end{array}$ & $\begin{array}{l}6 / 6 \\
4 / 4\end{array}$ & $\begin{array}{l}\text { Flat } \\
\text { All }\end{array}$ & $\begin{array}{l}6 / 6 \\
6 / 6\end{array}$ & Diffuse & $6 / 6$ & $\begin{array}{l}\text { Flat } \\
\text { All }\end{array}$ & $\begin{array}{l}6 / 6 \\
4 / 4\end{array}$ & $\begin{array}{l}\text { Flat } \\
\text { All }\end{array}$ & $\begin{array}{l}6 / 6 \\
6 / 6\end{array}$ & Diffuse & $4 / 4$ & $\begin{array}{l}31 / 32 \\
34 / 34\end{array}$ & $100 \%$ \\
\hline $\begin{array}{l}\text { See- } \\
\text { Write }\end{array}$ & $\begin{array}{l}\text { Flat } \\
\text { Diffuse } \\
\text { All }\end{array}$ & $\begin{array}{l}5 / 6 \\
3 / 4 \\
5 / 6\end{array}$ & $\begin{array}{l}\text { Compact } \\
(-) \text { Diffuse }\end{array}$ & $\begin{array}{l}6 / 6 \\
6 / 6\end{array}$ & $\begin{array}{l}\text { Compact } \\
(-) \text { Flat }\end{array}$ & $\begin{array}{l}4 / 4 \\
6 / 6\end{array}$ & $\begin{array}{l}\text { Compact } \\
\text { Diffuse }\end{array}$ & $\begin{array}{l}4 / 4 \\
6 / 6\end{array}$ & Diffuse & $6 / 6$ & Diffuse & $4 / 4$ & $31 / 32$ & $97 \%$ \\
\hline
\end{tabular}

Table 10

Those dimensions, or their combination, which best predict the intrusions in all four conditions. These dimensions are all taken from the TAA or CPA. A minus sign indicates predictions are based on a negative prediction hypothesis.

HT = height of tongue $; \mathrm{FB}=$ front-backness $; \mathrm{HT} / \mathrm{FB}=$ both dimensions considered together.

\begin{tabular}{|c|c|c|c|c|c|c|c|c|c|c|c|c|c|c|}
\hline Condition & I & & $\epsilon$ & & ae & & $\supset$ & & 0 & & $\mathrm{U}$ & & $\begin{array}{c}\text { Total } \\
\text { Binary }\end{array}$ & $\begin{array}{l}\% \text { Correct } \\
\text { Predictions }\end{array}$ \\
\hline $\begin{array}{l}\text { Hear- } \\
\text { Say }\end{array}$ & $\begin{array}{l}\mathrm{HT} / \mathrm{FB} \\
\mathrm{FB}\end{array}$ & $\begin{array}{l}6 / 6 \\
4 / 4\end{array}$ & $\begin{array}{l}\text { HT/FB } \\
\text { HT }\end{array}$ & $\begin{array}{l}6 / 6 \\
6 / 6\end{array}$ & HT/FB & $6 / 6$ & $\mathrm{HT} / \mathrm{FB}$ & $6 / 6$ & $\begin{array}{l}\text { HT/FB } \\
\text { HT }\end{array}$ & $\begin{array}{l}6 / 6 \\
6 / 6\end{array}$ & $\begin{array}{l}\mathrm{HT} / \mathrm{FB} \\
\mathrm{HT} \\
(-) \mathrm{FB}\end{array}$ & $\begin{array}{l}6 / 6 \\
6 / 6 \\
4 / 4\end{array}$ & & $100 \%$ \\
\hline $\begin{array}{l}\text { Hear- } \\
\text { Write }\end{array}$ & $\begin{array}{l}\mathrm{HT} / \mathrm{FB} \\
\mathrm{FB}\end{array}$ & $\begin{array}{l}5 / 6 \\
3 / 4\end{array}$ & $\begin{array}{l}\mathrm{HT} / \mathrm{FB} \\
\mathrm{HT}\end{array}$ & $\begin{array}{l}6 / 6 \\
6 / 6\end{array}$ & $\mathrm{HT} / \mathrm{FB}$ & $6 / 6$ & $\begin{array}{l}\mathrm{HT} / \mathrm{FB} \\
\mathrm{FB}\end{array}$ & $\begin{array}{l}6 / 6 \\
4 / 4\end{array}$ & $\mathrm{HT}$ & $6 / 6$ & HT/FB & $6 / 6$ & $36 / 36$ & $97 \%$ \\
\hline $\begin{array}{l}\text { See- } \\
\text { Say }\end{array}$ & FB & $4 / 4$ & HT & $6 / 6$ & FB & $3 / 4$ & $\begin{array}{l}\mathrm{HT} / \mathrm{FB} \\
\mathrm{HT}\end{array}$ & $\begin{array}{l}6 / 6 \\
6 / 6\end{array}$ & $\begin{array}{l}\text { HT } \\
(-) F B\end{array}$ & $\begin{array}{l}6 / 6 \\
4 / 4\end{array}$ & $\begin{array}{l}\text { HT/FB } \\
\text { FB }\end{array}$ & $\begin{array}{l}6 / 6 \\
4 / 4\end{array}$ & $31 / 32$ & $97 \%$ \\
\hline $\begin{array}{l}\text { See- } \\
\text { Write }\end{array}$ & $\mathrm{HT} / \mathrm{FB}$ & $6 / 6$ & $\begin{array}{l}\mathrm{HT} / \mathrm{FB} \\
\mathrm{HT}\end{array}$ & $\begin{array}{l}4 / 6 \\
4 / 6\end{array}$ & $\begin{array}{l}(-) \mathrm{HT} \\
\mathrm{FB}\end{array}$ & $\begin{array}{l}6 / 6 \\
4 / 4\end{array}$ & $\begin{array}{l}\mathrm{HT} / \mathrm{FB} \\
\mathrm{FB}\end{array}$ & $\begin{array}{l}6 / 6 \\
4 / 4\end{array}$ & $\begin{array}{l}\mathrm{HT} / \mathrm{FB} \\
\mathrm{FB}\end{array}$ & $\begin{array}{l}5 / 6 \\
3 / 4\end{array}$ & $\begin{array}{l}\mathrm{HT} / \mathrm{FB} \\
\mathrm{FB}\end{array}$ & $\begin{array}{l}6 / 6 \\
4 / 4\end{array}$ & $31 / 34$ & $91 \%$ \\
\hline
\end{tabular}

Table 11

Those dimension combinations (excluding all dimensions, together) which best predict the intrusions in all four conditions. These dimensional combinations are taken from Halle's (1962) distinctive feature system. $F=$ flat; $C=$ compact; $D=$ diffuse; $G=$ grave.

\begin{tabular}{|c|c|c|c|c|c|c|c|c|c|c|c|c|c|}
\hline \multicolumn{2}{|c|}{ Condition } & I & \multicolumn{2}{|c|}{$\epsilon$} & \multicolumn{2}{|l|}{$\mathrm{ae}$} & \multicolumn{2}{|c|}{$\supset$} & \multicolumn{2}{|l|}{0} & \multicolumn{2}{|c|}{$\mathbf{U}$} & $\begin{array}{l}\% \text { Correct Binary } \\
\text { Predictions }\end{array}$ \\
\hline $\begin{array}{l}\text { Hear- } \\
\text { Say }\end{array}$ & $\begin{array}{l}\text { FD } \\
\text { DG } \\
\text { CD } \\
\text { FCD } \\
\text { CDG }\end{array}$ & $\begin{array}{l}6 / 6 \\
6 / 6 \\
4 / 4 \\
6 / 6 \\
6 / 6\end{array}$ & $\begin{array}{l}\text { FD } \\
\text { DG } \\
\text { FG } \\
\text { FCD } \\
\text { CDG } \\
\text { FDG }\end{array}$ & $\begin{array}{l}4 / 4 \\
4 / 4 \\
6 / 6 \\
6 / 6 \\
6 / 6 \\
4 / 4\end{array}$ & $\begin{array}{l}\text { FD } \\
\text { DG } \\
\text { CG } \\
\text { FCD } \\
\text { CDG } \\
\text { FDG }\end{array}$ & $\begin{array}{l}4 / 4 \\
4 / 4 \\
6 / 6 \\
6 / 6 \\
6 / 6 \\
4 / 4\end{array}$ & $\begin{array}{l}\text { FD } \\
\text { DG } \\
\text { FC } \\
\text { CG } \\
\text { FCD } \\
\text { FDG }\end{array}$ & $\begin{array}{l}4 / 4 \\
4 / 4 \\
6 / 6 \\
6 / 6 \\
6 / 6 \\
4 / 4\end{array}$ & $\begin{array}{l}\text { FD } \\
\text { DG } \\
\text { FG } \\
(-) C D \\
\text { FDG }\end{array}$ & $\begin{array}{l}4 / 4 \\
4 / 4 \\
6 / 6 \\
4 / 4 \\
4 / 4\end{array}$ & $\begin{array}{l}\text { FD } \\
\text { DG } \\
\text { FC } \\
\text { FG } \\
\text { CG } \\
\text { FDG }\end{array}$ & $\begin{array}{l}6 / 6 \\
4 / 4 \\
4 / 4 \\
6 / 6 \\
4 / 4 \\
4 / 4\end{array}$ & $100 \%$ \\
\hline $\begin{array}{l}\text { Hear- } \\
\text { Write }\end{array}$ & $\begin{array}{l}\text { FC } \\
\text { CG } \\
\text { FCD } \\
\text { FCG } \\
\text { CDG }\end{array}$ & $\begin{array}{l}4 / 4 \\
4 / 4 \\
6 / 6 \\
4 / 4 \\
6 / 6\end{array}$ & $\begin{array}{l}\text { FC } \\
\text { FG } \\
\text { CG } \\
\text { FCD } \\
\text { FCG } \\
\text { CDG }\end{array}$ & $\begin{array}{l}4 / 4 \\
6 / 6 \\
4 / 4 \\
6 / 6 \\
4 / 4 \\
6 / 6\end{array}$ & $\begin{array}{l}\text { FC } \\
\text { FD } \\
\text { CG } \\
\text { DG } \\
\text { FCD } \\
\text { CDG } \\
\text { FDG }\end{array}$ & $\begin{array}{l}0 / 0 \\
4 / 4 \\
6 / 6 \\
4 / 4 \\
6 / 6 \\
6 / 6 \\
4 / 4\end{array}$ & $\begin{array}{l}\text { FC } \\
C D \\
C G \\
\text { FCD } \\
\text { CDG }\end{array}$ & $\begin{array}{l}6 / 6 \\
4 / 4 \\
6 / 6 \\
6 / 6 \\
6 / 6\end{array}$ & $\begin{array}{l}\text { FC } \\
\text { FG } \\
\text { CG } \\
\text { FCG }\end{array}$ & $\begin{array}{l}4 / 4 \\
6 / 6 \\
4 / 4 \\
4 / 4\end{array}$ & $\begin{array}{l}\text { FC } \\
\text { FD } \\
C G \\
\text { DG } \\
\text { FCD } \\
\text { FCG } \\
\text { CDG }\end{array}$ & $\begin{array}{l}4 / 4 \\
6 / 6 \\
4 / 4 \\
6 / 6 \\
6 / 6 \\
4 / 4 \\
6 / 6\end{array}$ & $100 \%$ \\
\hline $\begin{array}{l}\text { See-- } \\
\text { Say }\end{array}$ & $C D$ & $4 / 4$ & $\begin{array}{l}\text { FD } \\
\text { FG } \\
\text { DG } \\
\text { FDG }\end{array}$ & $\begin{array}{l}4 / 4 \\
6 / 6 \\
4 / 4 \\
4 / 4\end{array}$ & $\begin{array}{l}\text { FD } \\
\text { DG } \\
\text { FCD } \\
\text { CDG } \\
\text { FDG }\end{array}$ & $\begin{array}{l}4 / 4 \\
4 / 4 \\
6 / 6 \\
6 / 6 \\
4 / 4\end{array}$ & $\begin{array}{l}\text { FC } \\
\text { FD } \\
\text { FG } \\
\text { CG } \\
\text { DG } \\
\text { FCG } \\
\text { FDG }\end{array}$ & $\begin{array}{l}6 / 6 \\
4 / 4 \\
6 / 6 \\
6 / 6 \\
4 / 4 \\
6 / 6 \\
4 / 4\end{array}$ & $\begin{array}{l}\text { FD } \\
\text { FG } \\
(-) C D \\
\text { DG } \\
\text { FDG }\end{array}$ & $\begin{array}{l}4 / 4 \\
6 / 6 \\
4 / 4 \\
4 / 4 \\
4 / 4\end{array}$ & $\begin{array}{l}\text { FD } \\
\text { FG } \\
C D \\
\text { DG } \\
\text { FCD } \\
\text { CDG }\end{array}$ & $\begin{array}{l}6 / 6 \\
6 / 6 \\
4 / 4 \\
6 / 6 \\
6 / 6 \\
6 / 6\end{array}$ & $100 \%$ \\
\hline $\begin{array}{l}\text { See- } \\
\text { Write }\end{array}$ & $\begin{array}{l}\text { FC } \\
\text { FD } \\
C G \\
\text { DG } \\
\text { FCD } \\
\text { FCG } \\
\text { CDG }\end{array}$ & $\begin{array}{l}4 / 4 \\
6 / 6 \\
4 / 4 \\
6 / 6 \\
6 / 6 \\
4 / 4 \\
6 / 6\end{array}$ & $\begin{array}{l}\text { FC } \\
\text { CG } \\
\text { FCG }\end{array}$ & $\begin{array}{l}4 / 4 \\
4 / 4 \\
4 / 4\end{array}$ & $\begin{array}{l}(-) \mathrm{FG} \\
\mathrm{CD} \\
(-) \mathrm{FCG}\end{array}$ & $\begin{array}{l}6 / 6 \\
4 / 4 \\
6 / 6\end{array}$ & $\begin{array}{l}\text { FC } \\
\text { CD } \\
\text { CG } \\
\text { FCD } \\
\text { CDG }\end{array}$ & $\begin{array}{l}6 / 6 \\
4 / 4 \\
6 / 6 \\
6 / 6 \\
6 / 6\end{array}$ & $\begin{array}{l}\text { FD } \\
\text { DG } \\
\text { FCG }\end{array}$ & $\begin{array}{l}4 / 4 \\
4 / 4 \\
4 / 4\end{array}$ & $\begin{array}{l}\text { FD } \\
\text { CD } \\
\text { DG } \\
\text { FCD } \\
\text { CDG }\end{array}$ & $\begin{array}{l}6 / 6 \\
4 / 4 \\
6 / 6 \\
6 / 6 \\
6 / 6\end{array}$ & $100 \%$ \\
\hline
\end{tabular}


sound, or the acoustical properties of the speech wave. Thus, we should expect these distinctive feature systems to be most accurate in predicting intrusions in the Hear-Say condition. Since the results show that this condition was predicted perfectly by both CPA and TAA, these contentions concerning distinctive feature theories are supported. Furthermore, since the results show groupings (in accuracy of distinctive feature theories to predict intrusion data) on input modality (but not output modality), it appears that the type of input is more important in the encoding process. These results suggest that (a) sounds are both identified and coded primarily before the output stages, and (b) visual input either does not get recoded into the identical units that auditory input does, or that the recoding is not as predictable.

This study supports Wickelgren's 1965 argument that vowels are encoded as a set of distinctive features. Some qualifications to this statement, however, appear necessary. Only under specified conditions, considering both the stimuli used and the information processing variables, does one theory predict all of the intrusion errors. For example, CPA and TAA would predict $100 \%$ of the intrusion data for the Hear-Say condition, while predicting only $78 \%$ of the intrusions for the See-Say condition. In other cases, one feature system or set of dimensions will not be adequate to predict all of the errors for each processed sound. This conclusion is firmly supported by the pattern of results found in the two See conditions. In these cases, it is possible that vowel sounds are not encoded as a set of distinctive features at all, as Liberman et al (1967) strongly suggest.

This later explanation, however, appears inadequate. For example, Sales, Haber, and Cole (1968) found that although one dimension could not predict intrusion errors, intrusions for each sound could be predicted when predictions were based upon different dimensions for each sound. This result was replicated in this study for all four conditions! It thus appears that sounds are processed with all features being initially identified. However, the actual encoding in short-term memory involves different dimensions for each sound, depending upon the task involved.

In support of this notion, we found that (a) eliminating the tense-lax variants allows for $100 \%$ prediction of intrusion data using one dimension or some combination of dimensions, and (b) although negative predictions are useful when the tense-lax variant is present, eliminating these variants elevates predictions by a shared feature hypothesis. The greater predictability by the shared feature method may be accounted for by the fact that eliminating sounds with a tense-lax variant makes the discrimination task easier, since sounds are not so close in their feature specifications. Thus, both of the hypotheses made concerning the elimination of the tense-lax or open-close variant were supported in this experiment.

\section{REFERENCES}

COLE, R. A., HABER, R. N., \& SALES, B. D. Mechanisms of aural encoding: I. Distinctive features for consonants. Perception \& Psychophysics, 1968, 3, 281-284.

CONRAD, R., \& HULL, A. J. Input modality and the serial position curve in short-term memory. Psychonomic Science, 1968, 10, 135-136.

HALLE, M. Phonology in a generative grammar. Word, 1962, 18, 54-72.

LIBERMAN, A. M., COOPER, F. S., SHANKWEILER, D. P., \& STUDDERT-KENNEDY, M. Perception of the speech code. Psychological Review, 1967, 74, 431-461.

PIKE, K. L. Phonemics: $A$ technique for reducing languages to writing. Ann Arbor: University of Michigan Press, 1947. P. 5.

SALES, B. D., HABER, R. N., \& COLE, R. A. Mechanisms of aural encoding: III. Distinctive features for vowels. Perception \& Psychophysics, 1968, 4, 321-327.

WICKELGREN, W. A. Distinctive features and errors in short-term memory for English vowels. Joumal of the Acoustical Society of America, 1965, 38, 583-588.

WICKELGREN, W. A. Distinctive features and errors in short-term memory for English consonants. Journal of the Acoustical Society of America, 1966, 39, 388-398.

\section{NOTES}

1. This research was partially supported by a grant from the United States Public Health Service, MH 10753, and a grant from the National Science Foundation, GB 5910, to the second author. We would like to thank Linda C. Yaeger and Ronnie Bring for their assistance in collecting and analyzing data.

2. Address: Department of Psychology, University of Rochester, River Campus Station, Rochester, New York 14627.

3. More recent analyses using rank order predictions indicates that the input modalities may be the critical determinant of distinctive feature encoding. Accuracy of predictions were: (a) CPA-Hear-Write, 93\%; HearSay, 93\%; See-Say, 82\%; See-Write, 82\%; (b) Halle-Hear-Write, 96\%; Hear-Say, 96\%; See-Say, 77\%; See-Write, $73 \%$.

(Accepted for publication April 28, 1969.) 